Journal of Islamic Economics and Finance Studies

\title{
Preferensi Koperasi Dalam Melakukan Konversi Menjadi Koperasi Syariah: Studi Kasus Pada Koperasi Di Wilayah Bogor
}

\author{
Maya Apriyana \\ Universitas Djuanda \\ mayaapriana7@gmail.com \\ Sahlan Hasbi \\ Universitas Djuanda \\ Sahlan.Hasbi@gmail.com
}

Received: October 14, 2020 | Accepted: November 22, 2020 | Published: November 25, 2020

\begin{abstract}
This study aims to determine the most dominant factors affecting the cooperative preference in the conversion into a cooperative sharia. The research method using the quantitative approach to the technique of factor anaysis. The results indicate that regulatory support, promotion and profit sharing rate is the most dominant factor or a major factor for the preference of cooperative in the conversion into a cooperative sharia. Meanwhile religion, information, and image is a supporting factor for the preference of cooperatives in the conversion into a cooperative sharia.
\end{abstract}

Keywords: Preference, Cooperatative, Conversion, Sharia Cooperation

\begin{abstract}
Abstrak
Penelitian ini bertujuan untuk mengetahui faktor-faktor paling dominan yang mempengaruhi preferensi koperasi dalam melakukan konversi menjadi koperasi syariah. Metode penelitian menggunakan pendekatan kuantitatif dengan teknik analisis analisis faktor. Hasil penelitian ini menunjukan bahwa dukungan regulasi, promosi dan tingkat bagi hasil merupakan faktor yang paling dominan atau faktor utama untuk preferensi koperasi dalam melakukan konversi menjadi koperasi syariah. Sedangkan agama, informasi dan image merupakan faktor pendukung untuk preferensi koperasi dalam melakukan konversi menjadi koperasi syariah.
\end{abstract}

Kata Kunci : Preferensi, Koperasi, Konversi, Koperasi Syariah 


\section{PENDAHULUAN}

Indonesia mempunyai tiga pilar kekuatan ekonomi yang melaksanakan berbagai kegiatan usaha dalam tata kehidupan perekonomian, diantaranya Badan Usaha Milik Negara, Badan Usaha Milik Swasta dan Koperasi. Koperasi merupakan bagian tiga pilar perekonomian yang turut serta membantu kesejahteraan masyarakat, dan memilki peranan yang sangat penting dalam perekonomian nasional (Qurbani, 2015:1).

Koperasi memiliki sub unit simpan pinjam, yang merupakan media penyimpanan dan pinjaman bagi para anggotanya, dimana operasional transaksi menggunkan sistem bunga seperti halnya bank. Tingkat bunga pada keuangan konvensional termasuk koperasi merupakan salah satu pertimbangan anggota dalam memutuskan untuk menyimpan dan meminjam pada koperasi. Sistem bunga yang diberlakukan oleh lembaga keuangan konvensional maupun oleh koperasi merupakan bentuk riba yang dilarang di setiap agama termasuk agama Islam. Riba merupakan bantuk penambahan untuk mencapai keuntungan secara sepihak yang terdapat dalam transaksi yang dilakukan oleh lembaga keuangan konvensional (Lasmiatun, 2013:6).

Larangan sistem riba sesuai dengan ayat Al-Qur'an surah Al-Baqarah ayat 278, yang berarti "Hai orang-orang beriman! Bertakawalah kepada Allah dan tinggalkanlah sisa riba (yang belum dipungut) jika kamu orang yang beriman" dari ayat tersebut Allah memerintahkan untuk meninggalkan riba yang terdapat dalam praktik transaksi di lembaga keuangan konvensioal serta meninggalkan sisa riba yang belum diambil dan memerintahkan untuk melakukan transaksi-transaksi di lembaga keuangan yang sesuai dengan prinsip syariah (Khairina, 2017:15). Solusi yang dapat dilakukan oleh koperasi berserta pengurus dan anggota dengan merubah atau melakukan konversi dari sistem operasional transaksi konvensional berbasis bunga (riba) menjadi sistem operasional berdasarkan syariah.

Konversi dan akuisisi lembaga keuangan konvensional menjadi syariah menjadi trend pembetukan bank syariah di tahun 2008 (Anshari:2010) dan menjadi salah satu upaya yang dapat ditempuh untuk meningkatkan lembaga keuangan 
syariah khususnya koperasi syariah di Indonesia secara lebih cepat. Kondisi ini seriring dengan perkembangan koperasi syariah di Indonesia yang mengalami peningkatan yang signifikan selama 10 tahun terakhir seriring berkembangnya perbankan syariah di Indonesia (Rahayu, 2015:165). Sehingga perlu diketahui lebih lanjut faktor apa saja yang menjadi preferensi koperasi di wilayah Bogor untuk melakukan konversi menjadi koperasi syaraiah.

\section{TINJAUAN PUSTAKA}

Preferensi adalah objek yang dinilai sesuai dengan persyaratan yang dikehendakai, preferensi digambarkan sebagai sikap terhadap suatu barang atau jasa sebagai evaluasi dari sifat kognitif seseorang, dan terori preferensi digunakan untuk menganalisis tingkat kepuasan bagi konsumen (Aliyah, 2010:22). Preferensi juga diartikan sebagai sebuah konsep yang digunakan dalam ilmu sosial, khusunya ekonomi yang mengaangsumsikan pilihan realitas berdasarkan kesenangan, kepuasan dan gaya hidup (Barna, 2010:43). Berdasarkan beberapa pengertian preferensi di atas maka dapat di simpulkan bahwa preferensi merupkan penga,bilan keuputasan atas dasar kesukaan atau kesenangan pada sesesuatu secara rasional dan emosional.

\section{Faktor Yang Mempengaruhi Preferensi}

Faktor yang mempengaruhi preferensi terdapat tiga faktor yaitu faktor kebudayaan, faktor sosial, faktor psikologis dan faktor marketing mix. Adapun penjabarannya sebagai berikut: (Andespa, 2017:3)

1. Faktor Kebudayaan, yaitu terdiri dari budaya, sub-budaya dan kelas sosial. Budaya merupakan hasil kreativitas manusia dari generasi ke generasi berikutnya yang menentukan bentuk perilaku kehidupan sebagai anggota masyarkat meliputi ilmu pengetahuan, kepercayaan, seni, moral, adat kebiasaan dan norma-norma yang berlaku di masyarakat. Sub-budaya merupakan indentifikasi dan sosialisasi khas perilaku anggota masyarakat meliputi kebangsaan, agama, ras, dan daerah-daerah geografis. Dan kelas soaial merupakan suatu kelompok 
yang terdiri dari sejumlah orang yang mempunyai kedudukan yang berbeda. Faktor kebudayaan yang paling disoroti yaitu faktor agama, mayoritas masyarakat Indonesia yang beragama muslim seharusnya, masyarakat dan lembaga keuangan menggunakan sistem yang berbasis syariah.

2. Faktor Sosial, yaitu terdiri dari kelompok preferensi, keluarga dan peran dan status. Kelompok preferensi merupakan kelompok yang memiliki pengaruh secara langsung dan tidak langsung terhadap perilaku seseorang, dan mengikuti kebiasaan seseorang sehingga mempengaruhi pilihan dalam hal memilih. Keluarga merupakan unit masyarakat terkecil dengan perilaku yang sangat mempengaruhi dan menetukan pengambilan keputusan. Peran dan status merupakan partisipasi yang dilakukan oleh seseorang atau dengan banyak kelompok sehingga posisi seseorang dalam setiap kelompok disebut sebagai peran dan status.

3. Faktor Marketing Mix, yaitu bauran pemasaran yang mengacu pada stategi produk, distribusi, promisi dan penentuan harga yang bersifat unik dirancang untuk menghasilkan pertukaran yang saling memuaskan dengan pasar yang dituju.

4. Faktor Psikologis, yaitu terdiri dari motivasi dan persepsi. Motivasi merupakan keadaan yang ada pada diri seseorang yang mendorong untuk bertindak. Persepsi merupakan tindakan seseorang pada situasi dan kondisi yang sama dan apabila persepsi ada pada situasi yang berbeda maka tindakanya pun berbeda.

\section{Koperasi}

Koperasi adalah badan usaha yang beranggotakan orang perseorangan atau badan hukum koperasi dengan melandaskan kegiatan yang berlandaskan prinsip koperasi sekaligus gerakan ekonomi rakyat beradasarkan atas asas kekeluargaan sebagaimana yang dimaksud dalam peraturan perundang-undangan perkoperasian. Koperasi dikelola berasakan kekeluargaan, yang diartikan sebagai pengeloaan bersama secara demokratis dan terbuka. Tujuan koperasi yaitu untuk memajukan kesejahteraan anggota khususnya masyarakat dan umumnya untuk membangun tatanan perekonomian nasional dalam rangka mewujudkan masyrakat yang maju, 
adil, dan makmur yang berlandaskan Pancasila dan Undang-undang. Dengan prinsip koperasi sebagai ketentuan pokok yang berlaku dalam koperasi dan dijadikan sebagai pedoman kerja koperasi. (Undang-undang Nomor 17 Tahun 2012 Pasal 1,2,3)

\section{Konversi}

Konversi adalah perubahan dari satu sistem pengetahuan ke sistem pengetahuan yang lain (Kamus Besar Online). Konversi pada lembaga keuangan dari konvensional menjadi lembaga keuangan syariah adalah perubahan sistem, kebijakan, prinsip dan peraturan serta pengaturan mengenai lembaga keuangan konvensional menjadi lembaga keuangan syariah (Damanuri, 2016:24).

1. Mekanisme perubahan atau konversi koperasi menjadi koperasi syariah, adapun penjabarannya sebagai berikut:

Pertama, koperasi dapat mengubah kegiatan usahanya menjadi Usaha Simpan Pinjam dan Pembiayaan Syariah (KSPPS) atas persetujuan rapat anggota.

Kedua, jika telah mendapat pertujuan maka dapat dilaksanakan kegiatan usaha berdasarkan prinsip syariah paling lama dua tahun sebelum perubahan anggaran dasar.

Ketiga, setelah melaksanakan perubahan anggaran dasar menjadi KSPPS wajib melaksanakan dan mematuhi prinsip syariah.

Keempat, menyelesaikan perubahan dan disetujui oleh Menterimaka KSPPS kegiatan usaha berdasarkan prinsip syariah dalam jangka waktu satu tahun.

Kelima, KSPPS atau USPPS dan KSP atau USP yang telah merubah kegiatan usaha menjadi berdasarkan prinsip syariah tidak dapat berubah kembali menjadi KSP atau USP koperasi (Peraturan Menteri Koperasi Usaha Kecil dan Menengah Repbulik Indonesia, 2-17: 15-16)

2. Persyaratan perubahan atau konversi koperasi menjadi koperasi syariah. Persyaratan yang harus dipenuhi oleh koperasi dalam melakukan konversi menjadi koperasi syariah, harus memenuhi persyaratan dengan melampirkan dokumen sebagai berikut: 
a. Bukti kepemilikan modal sendiri

b. Rancanagan kerja paling sedikt tiga tahun yang menjelaskan hal sebagai berikut:

1. Rancangan Permodalan

2. Rancangan Kegiatan Usaha

3. Rancangan Bidang Operasional dan Sumber Daya Manusia

\section{Koperasi Syariah}

Koperasi syariah adalah koperasi yang menjalankan usaha di bidang simpan pinjam dan pembiayaan yang berpinsip syariah. Koperasi syariah identok dengan baitul maal watamwi (bmt). Pertumbuhan koperasi syariah tumbuh dengan kegiatan usaha yang tidak seragam, diantaranya memiliki beberapa jenis nama seperti Koperasi Simpan Pinjam Pembiayaan Syariah (KSPPS), dan Unit Usaha Simpan Pinjam dan Pembiayaan Syariah (UPPS). (Peraturan Menteri Koperasi dan UMKM, 2017:1).

Ruang lingkup kegiatan usaha koperasi syariah meliputi beberapa kegiatan, diantaranya:

1. Menyelengarakan kegiatan maal untuk pemberdayaan anggota dan masyarakat di bodang sosial.

2. Menghimpun simpanan berjangka dan tabungan koperasi dari anggota, calon anggita, koperasi lain dan/ atau anggotanya berdasarkan akad wadiah dan mudharabah.

3. Menyalurkan pinjaman kepada anggota, calon anggota, koperasi lain dan/atau anggotanya sesuai dengan akad.

4. Akad penyaliran pinjaman dan pembiayaan dapat dikombinasikan sesuai dengan Fatwa Dewan Syariah Majelis Ulama Indonesia (DSN-MUI). (Peraturan Menteri Koperasi dan UMKM Tahun 2017 Pasal 19). 


\section{METODE PENELITIAN}

Metode penelitian ini berjenis penelitian kuantitatif dengan teknik analisis menggunakan teknik analisis faktor. Obyek dalam penelitian ini adalah koperasi yang ada di wilayah Bogor dan subyek penelitian ini yaitu para pengurus koperasi baik ketua koperasi, manajer, teller, customer service, dan pemangku kebijakan serta sampel sebanyak 30 koperasi. Teknik pengumpulan data yang dilakukan yaitu penyebaran kuesioner dengan pengukuran variabel 4 sangat setuju, 3 setuju, 2 tidak setuju dan 1 sangat tidak setuju.

\section{HASIL DAN PEMBAHASAN}

Uji reliabilitas pada penelitian ini dilakukan pada kuesioner yang diambil dari 30 koperasi di wilayah Bogor dan diolah dengan aplikasi SPPS versi 22, dengan motode cronbach's alpha dan digunakn untuk mengukur tingkat ketetapan indikatorindikator dalam kuesioner penelitian ini. Pengambilan keputusan dalam metode ini adalah jika cronbach's alpha $<0,60$ maka kontruk dikategorikan kurang andal-cukup andal, dan sebaliknya jika cronbach's alpha $>0,60$ maka kontrok dikategorikan andalsangat andal (Putra,dkk, 2014:178). Berikut hasil reliabilitas dan validitas dengan menggunakan SPPS versi 22:

Tabel 1. Realiability Statistic

\begin{tabular}{|c|c|}
\hline Cronbach's Alpha & $N$ of Items \\
\hline 912 & 22 \\
\hline
\end{tabular}

Berdasarkan Tabel 1. di dapatkan jika nilai cronbach's alpha sebesar 0,912>0,60 yang berarti kontruk ini masuk dalam kategori andal-sangat andal, maka dapat disimpulkan bahwa 22 pertanyaan dalam kuesioner yang ada dalam penelitian ini adalah reliabel. Selanjutnya adalah uji validitas yang digunakan untuk menunjukan sejauh mana instrumen dapat diukur dan layak digunakan sebagai instrumen penelitian. Adapun kriteria validitas dari masing-masing pertanyaan dengan corrected item-total correlation harus lebih besar atau sama dengan nilai $r$ tabel. Oleh 
kerena itu, instrumen penelitian ini dinyatakan valid apabila hasil uji >0,361 ( $r$ tabel).

Berikut merupakan hasil uji validitas dengan menggunakan SPPS versi 22:

Tabel 3. Hasil Uji Validitas Item -Total Statistics

\begin{tabular}{|c|c|c|c|c|}
\hline \multicolumn{2}{|c|}{$\begin{array}{c}\text { Scale Mean if Item } \\
\text { Deleted }\end{array}$} & \multirow{2}{*}{$\begin{array}{c}\text { Scale Variance } \\
\text { if Item Deleted }\end{array}$} & \multirow{2}{*}{$\begin{array}{c}\begin{array}{c}\text { Correted Item- } \\
\text { Total Correations }\end{array} \\
, 568\end{array}$} & \multirow{2}{*}{$\begin{array}{c}\text { Cronbach's Alpha } \\
\text { if Item Deleted }\end{array}$} \\
\hline A.a.1 & 64,97 & & & \\
\hline B.a.1 & 65,17 & 65,592 & 540 & 909, \\
\hline B.b.1 & 64,83 & 66,695 & 479, & 910 \\
\hline C.b.1 & 64,83 & 68,213 & ,424 & 911 \\
\hline D.b.1 & 65,30 & 67,045 & 450 & 910 \\
\hline D.c.2 & 65,10 & 66,438 & ,426 & 911 \\
\hline A.d.1. & 65,10 & 65,817 & ,446 & 911 \\
\hline B.d.1 & 65,17 & 67,661 & 381 & 912, \\
\hline C.d.1 & 65,27 & 65,099 & ,488 & 910 \\
\hline D.d.1 & 65,20 & 67,338 & 540 & 909 \\
\hline A.e. 2 & 65,37 & 67,275 & 498 & 910 \\
\hline C.e. 2 & 65,03 & 66,102 & 565 & 908 \\
\hline B.f.1 & 64,93 & 65,651 & ,562 & 908 \\
\hline A.g. 2 & 65,00 & 65,241 & 578 & 908 \\
\hline B.g.2 & 65,23 & 64,254 & 618 & 907 \\
\hline C.g.2 & 65,33 & 62,989 & 674 & 905 \\
\hline D.g. 2 & 65,33 & 60,920 & 690, & 905 \\
\hline A.h.3 & 64,87 & 65,982 & 632 & 907, \\
\hline B.h.3 & 64,97 & 66,585 & 614 & 908 \\
\hline C.h.3 & 65,03 & 66,723 & 658 & 907 \\
\hline D.h.3 & 64,93 & 66,478 & 605 & 908 \\
\hline B.i.4 & 65,23 & 64,668 & 630 & 907 \\
\hline
\end{tabular}

Sumber: Data Penelitian Diolah, 2020 
Tabel 3 menunjukan bahwa jumlah pertanyaan sebanyak 36 pertanyaan, setelah melakukan uji validitas pertanyaan yang memiliki nilai corrected item-total correlation $>0,361$ sebanyak 14 pertanyaan, sehingga jumlah pertanyaan yang lulus uji validitas sebanyak 22 pertanyaan. Hasil ini menunjukan bahwa 22 pertanyaan variabel yang digunakan dalam kuesioner untuk mengetahui faktor agama, sosial, marketing mix, dan psikologis terhadap preferensi koperasi dalam melakukan konversi menjadi koperasi syariah adalah valid.

\section{Hasil Analisis Faktor}

Penelitian ini menggunakan 9 indikator atau faktor yang disebar pada 36 pertanyaan yang mengarahkan responden pada faktor mana yang paling dominan dan mempengaruhi preferensi dalam melakukan konversi. Kuesioner ini menerapkan skala likert dengan skor paling tinggi yaitu 4 dan skor paling rendah yaitu 1, dengan jumlah responden 30 orang. Untuk lebih jelas terdapat beberapa tahapan dalam analisis faktor, sebagai berikut:

\section{a. Uji Kaiser Mayer Olkin}

Uji ini digunakan untuk menunjukan metode sampling yang diterapkan setelah memenuhi syarat kecukupan sampel secara menyeluruh atau tidak. Batas nilai Kaiser Mayer Olkin (KMO) adalah 0,5 sehingga nilai KMO harus $>0,5$ agar dapat ditelaah lebih lanjut. Hasil pengeloaan data melalui program SPPS 22 diperokeh hasil pengolahan sebgaai berikut:

Tabel 4. Kaiser Mayer Olkin

\begin{tabular}{ccc}
\hline Kaisar-Mayer-Olkin Measure of Sampling Adequancy &, 607 \\
\hline Bartlett's Test of Sphericity & Approx Chi Square & 31,956 \\
& Df & 36 \\
& Sig &, 661 \\
\hline Sumber: Data Penelitian Diolah, 2020 & &
\end{tabular}


Tabel 4 diperoleh angka Kaiser Mayer Olkin Measure of Sampling Adequancy (KMO-MSA) mencapai 0,607. Hal ini termasuk ketegori baik mengingat angka KMO-MSA telah melebihi batas nilai KMO yaitu 0,5. Sehingga nilai KMO 0,607>0,5. Adapun nilai bartllets's test of sphercity mempunyai nilai 31,957 dengan nilai sigfinifikansi 0,661. Nilai ini menunjukan bahwa faktor pembentuk variabel sudah baik serta boleh dianalisis ke tahap selajutnya.

b. Proses Ekstraksi

Proses ekstraksi merupakan proses inti dari analisis faktor, yaitu melakukan proses ekstraksi pada sekumpulan variabel yang sudah lulus dalam uji validitas sebelumnya. Sehingga akan membentuk satu hingga lebih faktor. Pada proses ekdtraksi faktor ini menggunkan IBM SPPS 22 dengan metode ekstraksi Principal Component Analysis (PCS) dengan tingkat eigenvelue < 1akan dikeluarkan. Dari ekstraksi ini didapat tabel communalities, tabel total variance explained, dan tabel component matrix sebagai berikut:

Tabel 5. Communalities

\begin{tabular}{lcc}
\hline & Intial & Extraction \\
\hline Agama & 1,000 &, 300 \\
Dukungan Regulasi & 1,000 &, 617 \\
Informasi & 1,000 &, 443 \\
Aksesbilitas & 1,000 &, 304 \\
Promosi & 1,000 &, 551 \\
Image & 1,000 &, 420 \\
Tingkat Bagi Hasil & 1,000 &, 653 \\
Prospek Peluang Pasar & 1,000 &, 470 \\
Peean dan Status & 1,000 &, 046 \\
\hline
\end{tabular}

Sumber: Data Penelitian Diolah, 2020

Komunalitas merupakan proporsi varian variabel yang dapat dijelaskan oleh faktor, semakin besar nilai komalitas, maka semakin besar pula hubungan antar variabel dengan faktor. Nilai intial menghasilkan hubungan antar variabel berdasarkan faktor yang terbentuk. Semua intial bernilai 1, hal ini berarti varian 
variabel dapat didefinisikan pada faktor yang telah terbentuk. Nilai komunalitas extraction menghasilkan seberapa besar presentase varian yang dapat dijelaskan oleh faktor yang akan dibentuk. Selanjutnya berdasarkan pengolahan data dengan aplikasi SPSS 22 di dapatkan hasil bahwa 9 indikator yang digunakan akan dikelompokan ke dalam 2 faktor sebagaimana terdapat pada tabel 1.5 sebagai berikut:

Tabel 6. Total Variance Explained

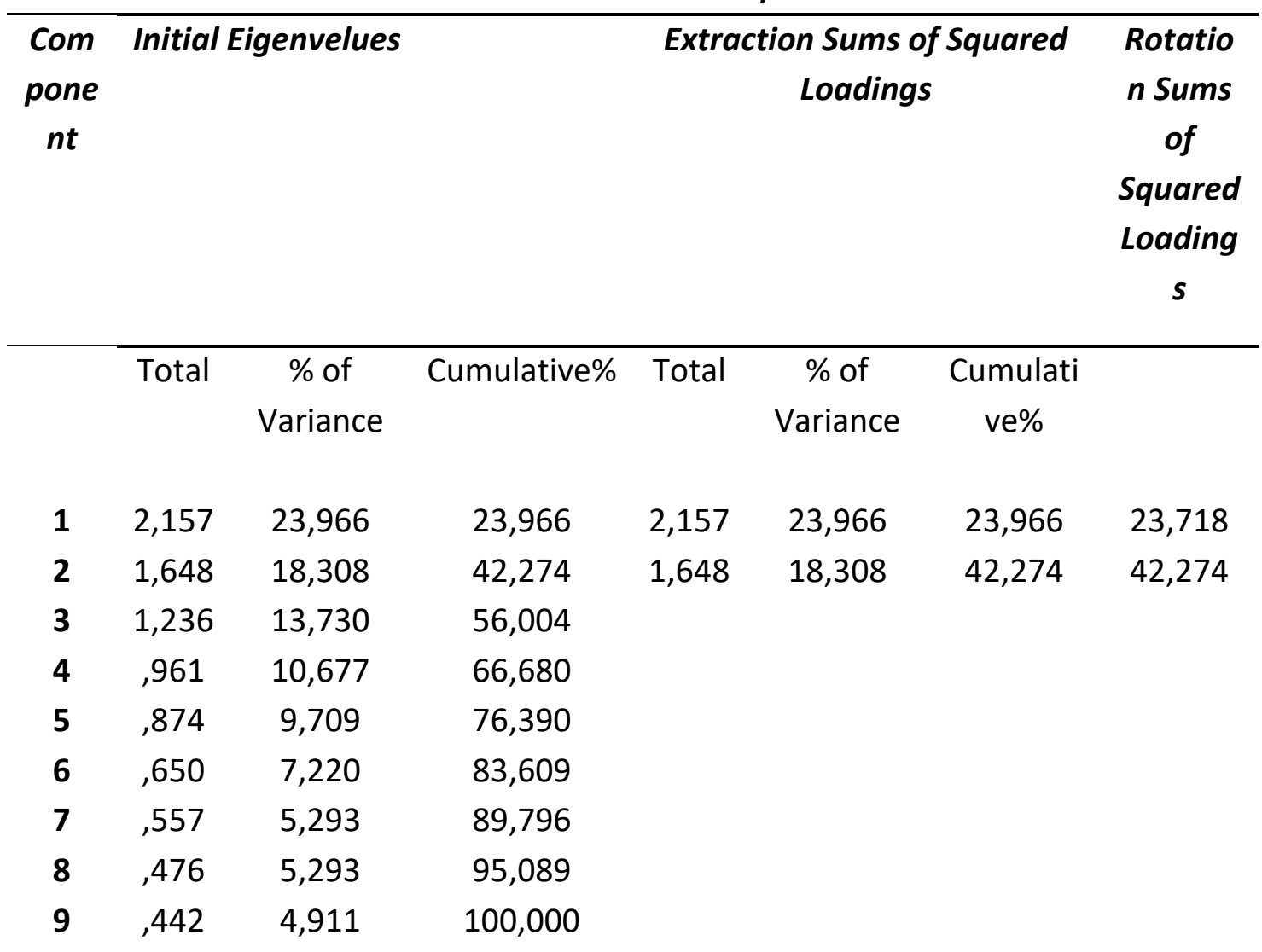

Extraction Method: Principal Component Analysis

Sumber: Data Penelitian Diolah, 2020

Berdasarkan output total variance indikator dapat diketahui bahwa:

1. Faktor pertama memiliki nilai eigenvalue sebesar 2,157 dengan varian 23,966 persen.

2. Faktor kedua memiliki nilai eigenvalue sebesar 1,648 dengan varian 18,308 persen. 
Hasil tersebut menyatakan bahwa faktor 1 mampu menjelaskan seluruh varian sebesar 23,966 persen, faktor 2 mampu menjelaskan seluruh varian sebesar 18,308 persen, Sedangkan komulatif seluruh faktor dapat menjalskan varian 42, 274 persen. Hal ini menunjukan bahswa masih terdpat variabel-variabel lain yang menjadi indikator dalam preferensi koperasi dalam melakukan konversi.

Setelah disapatkan 2 faktor yang merupakan jumlah yang paling idieal, maka analisis selanjutnya dilakukan pada component metrix yang merupakan factor of loading dan menunjukan besar korelasi antara suatu variabel dengan faktor pertama dan kedua. Proses penentuan variabel asal pada faktor dilakukan dengan membandingakan besar korelasi tiap baris yang didasarkan pada angka mutlak factor of loading yang memberikan setiap indikator terhadap masing-masing faktor.

Berdasarkan comoponent matrix, keseluruhan inikator berada pada faktor 1 dengan factor of loading lebih fari 0,5 dan tidak ada indikator yang masuk pada faktor 2 karena keseluruhan nilai factor of loading kurang dari 0,5. Syarat suatu inidkator masuk ke dalam suatu faktor yaitu factor of loading harus di atas 0,5. Maka dari itu, perlu adanya proses rotasi agar comopent 2 memilki nilai factor of loading yang besar, sehingga dapat terlihat variabel mana yang masuk pada component 2 . Proses rotasi menggunakan metode varimax yang bertujuan untuk membersarkan nilai factor of loading yang awalnya memang sudah kecil, sehingga diperoleh distribusi factor of loading yang terdapat pada Tabel 7, sebagai berikut: 
Tabel 7. Stucutre Matrix

\begin{tabular}{l|c|c}
\hline \multicolumn{3}{c}{ Component } \\
\hline \multicolumn{1}{c}{1} & 2 \\
\hline Agama &, 160 &, 524 \\
Dukungan Regulasi &, 784 &,- 050 \\
Tingkat Bagi Hasil &, 039 &, 665 \\
Peran dan Status &,- 055 &,- 549 \\
Informasi &, 708 &, 225 \\
Aksesbilitas &,- 307 &, 571 \\
Promosi &, 803 &, 085 \\
Prospek Peluang Pasar &, 470 &,- 500 \\
Image &, 170 &,- 131 \\
& \\
\hline Extraction Method: Pricipal Component Anaysis \\
\multicolumn{2}{l}{ Sumber: Data Penelitian Diolah, 2020 }
\end{tabular}

Sumber: Data Penelitian Diolah, 2020

Setalah dilakukan rotasi, maka dapat dengan mudah menetukan indikatorindikator mana yang masuk kedalam 2 faktor tersebut. Dari hasil rotated component matrix dapat dilihat bahwa variabel yang masuk dalam component 1 yaitu indikator dukungan regulasi $(0,784)$, promosi $(0,708)$, dan tingkat bagi hasil $(0,803)$. Hasil ini menyatakan bahwa inidkator tersebut memilki korelasi yang tinggi terhadap faktor 1. Kudia component 2 menyatakan bahwa indikator agama $(0,545)$, informasi $(0,658)$ dan image $(0,571)$ memiliki korelasi tinggi terhadap faktor 2 .

c. Penanaman Faktor

Berdasarkan hasil penelitian dari analisis faktor yang talah dijelaskan di atas dapat dirinci sebagai berikut yang dapat dilihat pada Tabel 8. 
Tabel 8. Faktor-faktor yang Dominan Mempengaruhi Preferensi Koperasi dalam Melakukan Konversi menjadi Koperasi Syariah

\begin{tabular}{llccc}
\hline Faktor & \multicolumn{1}{c}{ Variabel Asal } & Nilai Faktor & Eigenvalue & Varian (\%) \\
\hline Faktor I & Dukungan Regulasi & 0,784 & & \\
& Promosi & 0,708 & 2,157 & 23,966 \\
& Tingkat Bagi Hasil & 0,803 & & \\
\hline
\end{tabular}

Sumber: Data Diolah, 2020

$$
F_{1}=0,784 \text { Dukungan Regulasi }+ \text { 0,708 Promosi }+ \text { 0,803 Tingkat Bagi Hasil }
$$

Faktor pertama memiliki eigenvalue sebesar 2, 157 sehingga dapat disimpulkan bahwa ini merupakan faktor yang paling mempengaruhi preferensi koperasi dalam melakukan konversi menjadi koperasi syariah. Faktor 1 dapat mempengaruhi keragaman data sebesar 23,966. Dikelompokan kedalam faktor pertama yang terdiri dari dukungan regulasi, promosi, dan tingkat bagi hasil.

Dukungan regulasi merupakan dukungan yang diberikan oleh pemerintah berupa kebijakan dan peraturan berupa undang-undang. Dalam bentuk dikeluarkannya peraturan pemerintah mengenai perubahan status atau knversi yang tertera pada Peraturan Pemerintah Koperasi dan Usaha Kecil dan Menengah Republik Indonesia Nomor 16/Per/M.Kukm.IX/2015 tentang pelaksanaan kegiatan usaha simpanan pinjaman dan pembiayaan syariah oleh koperasi. Dukungan regulasi dari pemerintah juga dilakukan dalam bentuk pelatihan yaitu dengan dilaksanakananya pelatihan-pelatihan pola sistem syariah dari dinas koperasi yang diikuti oleh koperasi.

Program dilakukan untuk meningkatkan produk maupun jasa dalam hal menarik perhatian anggota koperasi. Promosi merupakan bagian yang sangat mempengaruhi preferensi koperasi dalam melakukan konversi menjadi koperasi syariah diantaranya banyaknya peluang kerjasama yang ditawarkan oleh lembaga keuangan syariah dan ajakan para ulama untuk melakukan transaksi-transaksi yang sesuai dengan syariah. Promosi yang dilakukan dalam mencari dana dari masyarakat dalam jumlah yang besar diperlukan promosi produk-produk koperasi syariah dengan media cetak mapun media elektronik seperti kalender, brosur, banner dan lain 
sebagainya. Sedangkan untuk media elektronik bisa menggunakan media elektronik pada umumnya seperti website, facebook, whatshaap dan lain sebagainya. Ditengah kemajuan teknologi seperti sekarang ini, promosi menggunakan media elektronik lebih evektif, hal ini dikarenakan sudah banyaknya masyarakat yang familiar dengan media internet serta memudahkan promosi dan pemsaran untuk koperasi syariah (Yusuf, 2015:6) sehingga promsi menjadi pertimbangan koperasi untuk melakukan perubahan atau konversi menjadi koperasi syariah.

Tingkat bagi hasil merupakan keuntungan atau hasil yang diperoleh dari pengeloaan dana baik investasi mauun transaksi jual beli anatara koperasi dengan anggota koperasi, dan sesuai dengan kesepakatan perjanjian di awal akad. Tingkat bag hasil pada koperasi syariah dapat menarik perhatian dari masyarakat saat ini, karena sistem bagi hasil yang diterapkan dan tidak mengandung riba atau bunga didalamnya. Salah satu faktor perkembangan koperasi syariah adlah mengenai respon masyarakat atau anggota koperasi terhadap produk mudharabah. Dalam transaksi mudharabah anggota koperasi syariah bertindak sebagai pengelola dana dan anggota koperasi bertindak sebagai pemilik dana (Amelia, 2016:2).

Tabel 9. Faktor-Faktor Pendukung yang Mempengaruhi Preferensi Koperasi dalam Melakukan Konversi Menjadi Koperasi Syariah

\begin{tabular}{llccc}
\hline Faktor & Variabel Asal & Nilai Faktor & Eigenvalues & $\begin{array}{c}\text { Varians } \\
\text { (\%) }\end{array}$ \\
\hline Faktor 2 & Agama & 0,524 & & \\
& Informasi & 0,669 & 1,648 & 18,303 \\
& Image & 0,571 & & \\
\hline
\end{tabular}

Sumber: Data Diolah, 2020

Maka dapat dibuat persmaan untuk faktor pendukung adalah sebagai berikut:

$$
\mathrm{F}_{2}=0,524 \text { Agama + 0, } 669 \text { Informasi + 0, } 571 \text { Image }
$$

Faktor kedua memilki eigenvalues sebesar 1,648 sehingga dapat disimpulkan bahwa ini merupakan faktor pendukung yang mempengaruhi preferensi koperasi dalam melakukan konversi menjadi koperasi syariah, faktor 2 dapat mempengaruhi keragaman data sebesar 18,303. 
Agama merupakan kepercayaan dan upacara ritual yang dimilki bersama oleh suatu kelompok masyarakat, dan agama merupakan bagian penting dalam kehidupan masyarakat. Agama dalam hal ini merupakan bentuk larangan yang terdapat di setiap agama dalam melakukan transkasi jual beli yang tidak merugikan salah satu pihak atau tidak mengandung bunga di dalam kegiatan transaksi tersebut (Marzali, 2016:3).

Informasi merupakan penyampaian dalam bentuk lisan maupun tuliasan (Amiq1, 2015:356). Informasi yang dimaksud dalam penelitian ini adalah infomarsi mengenai tata cara dalam melakukan konversi atau pola sistem koperasi syariah, yang disampaikan oleh dinas koperasi maupun oleh pihak koperasi itu sendiri dalam mecari informasi mengenai konversi.

Image merupakan salah satu hal yang paling mudah diingat oleh benak anggota koperasi, atau dapat diartikan sebagai kepercayaan anggota koperasi sebagai pembeda dari lembaga keuangan lainnya, seperti lambang, huruf dan lambang khusus (Zenul, 2017:45). Image merupakan hal yang perlu diperhatikan secara khusus oleh lembaga keuangan seperti koperasi, karena ini akan menjadi penarik anggota koperasi dan memberikan kepercayaan anggota karna memiliki image yang baik. Ketika koperasi memiliki image yang baik, anggota koperasi tidak akan ragu dalam melakukan transaksi di koperasi, bahkan akan menjadikan ajang promosi mulut ke mulut. Sehingga image perlu dibangun sebaik mungkin untuk mengahasilkan anggota yang loyal.

\section{SIMPULAN}

Setelah melakukan penelitian mengenai preferensi koperasi dalam melakukan konversi menjadi koperasi syariah di wilayah Bogor, terdapat beberapa kesimpulan yang dapat dijelaskan, pertama hasil uji validitas dan realibilitas variabel pengukuran pada penelitian ini yang dilihat dari hasil uji SPPS 22, menunjukana bahwa nilai perolehan alfa cronbach's adalah $0.910 \geq$ dari 0.60 yang berarti konstruk ini masuk dalam kategori andal-sangat andal, atau dengan kata lain dapat dikatakan 22 pertanyaan dan pernyataan dalam penelitian ini adalah realiabel. Sedakang uji validitas harus $\geq 0.361$ keseluruhan variabel dari A.a.1 sampai A.i.4 rata-rata memilki 
nilai $\geq 0.361$ dan 14 pernyataan yang nilainya dibawah 0.361 . hasil ini menunjukan bahwa 22 pernyataan yang digunakan dalam penelitian untuk mengetahui preferensi koperasi dalam melakukan konversi menjadi koperasi menjadi koperasi syariah adalah valid. Kedua faktor yang mempengaruhi preferensi koperasi dalam melakukan konversi adalah faktor agama, dukungan regulasi, informasi, aksesbilitas, promosi, image, tingkat bagi hasil, prospek peluang pasar serta peran dan status. Ketiga faktor yang paling dominan adalah faktor dukungan regulasi, promosi dan tingkat bagi hasil.

\section{DAFTAR PUSTAKA}

Al-Qur'an

Aliah, Wailatul. 2010. Preferensi Nasabah Terhadap Kredit Pemilikan Rumah Syariah Universitas Islam Negeri Islam Syarif Hidayatullah: Jakarta

Andespa, Roni. Faktor-Faktor yang mempengaruhi Minat Nsabah dalam Menabung di Bank Syariah. Jurnal Al-Masraf Lembaga Keuangan dan Perbankan Vol 2 No.1

Anshari,G.A. 2010. Konversi Bank Konvensional Menjadi Bank Syariah Ditinjau dari Hukum Postif dan Hukum Islam. Sumedang: UPI Sumedang Press

Arifin, 2014. Pengembangan Produk-Produk Lembaga Keuangan Mikro Syariah. Jurnal Equibrium Vol 2 No.1

Barna, Putri.2010. Analisis Faktor-Faktor yang Mempengaruhi Preferensi Nasabah Bank Syariah (Studi Kasus pada Bank Mega Syariah KCP Panglima Polim) Univeritas Islam Negeri Syarif Hidayatullah: Jakarta

Khairina, Syifa.2017. Analalisi Preferensi UMKM terhadap Pembiayaan Syariah di Kota Depok, Institut Pertanian Bogor: Bogor

Kusdayanti,N.2016. Pengaruh Citra Koperasi dan Kualitas Pelayanan Terhadap Kepuasan Anggota Koperasi Pegawai Repubik Indonesia Setia Kecematan Mijikerto Kabuparen Wonosobo, Universitas Negeri Yogjarta: Jogjarta

Lasmiatun, 2013. Prospek Lembaga Keuangan Mikro Syariah dalam Mendukung Pembiayaan Usaha Berskala Mikro untuk Pengetasan Kemiskinan. Jurnal Dharma Ekonomi Vol.2 No.1

Rahayu, Sri. 2015. Kontribusi Lembaga Keuangan Mikro Syariah Terhadap Pemberdayaan Perempuan (Studi Kasus BMT di Kabupaten Sleman Yogjakarta). Jurnal Inovasi dan Kewirausahaan. Vol 4 N.3

Umiyati, 2009. Model Konversi Operasional dan Pencataan Akutansi Unit Usaha Simpan Pinjam Koperasi Pegawai dengan Pola Syariah: Studi Kasus 
Journal of Islamic Economics and Finance Studies (JIEFeS)

Koperasi Pegawai UIN Syarif Hidayatullah Jakarta, Jurnal Ekonomi Universitas Inslam Negeri Syarif Hidayatullah Jakarta Vol 8 No.3

https://kotabogor.go.id

https://bogorkab.go.id 